\title{
Pola Penanda Glikemik dan Inflamasi dalam Perkembangan Penyakit Diabetes Melitus Tipe 2 pada Pria Obesitas Sentral
}

\author{
Miftakh N. Rahman ${ }^{1,2}$, Indriyanti R. Sukmawati' ${ }^{2}$ Irma M. Puspitasari ${ }^{1,3}$ \\ 1Program Studi Magister Farmasi Klinik, Fakultas Farmasi, Universitas Padjadjaran, \\ Bandung, Indonesia, ${ }^{2} \mathrm{PT}$. Prodia Widyahusada Tbk. Jakarta Pusat, Indonesia, \\ ${ }^{3}$ Pusat Unggulan Iptek Perguruan Tinggi Inovasi Pelayanan Kefarmasian, \\ Universitas Padjadjaran, Sumedang, Indonesia
}

\begin{abstract}
Abstrak
Obesitas sentral merupakan masalah kesehatan yang prevalensinya terus bertambah. Obesitas sentral telah diketahui menjadi faktor risiko yang berasosiasi kuat dengan diabetes melitus (DM). Obesitas sentral memicu inflamasi yang menyebabkan resistensi insulin dan peningkatan fungsi sel beta pankreas sebagai kompensasi hingga akhirnya mengalami kerusakan. Oleh karena itu, perlu diketahui pola penanda glikemik dan inflamasi dalam perkembangan penyakit DM. Penelitian ini bertujuan untuk mengetahui pola penanda glikemik dan inflamasi dalam perkembangan penyakit DM pada pria dengan obesitas sentral. Penelitian dilakukan dengan pendekatan potong lintang terhadap 70 orang pria berusia 30-50 tahun di Jakarta, Bandung, Semarang, dan Bogor dengan lingkar perut lebih dari 90 $\mathrm{cm}$ yang memenuhi kriteria inklusi dan eksklusi dan diperiksakan HbA1c, insulin puasa, glukosa puasa, serta hsCRP. HOMA-IR dan HOMA-B diperoleh dari permodelan matematika untuk insulin puasa dan glukosa puasa. Rekrutmen dilakukan pada bulan November-Desember 2017. Diperoleh hasil bahwa terdapat korelasi positif antara lingkar perut dengan $\mathrm{HbA} 1 \mathrm{c}(\mathrm{r}=0,484 ; \mathrm{p}<0,05)$, insulin puasa $(\mathrm{r}=0,629 ; \mathrm{p}<0,05)$, HOMA-IR $(\mathrm{r}=0,602 ; \mathrm{p}<0,05)$, HOMA-B $(\mathrm{r}=0,540 ; \mathrm{p}<0,05)$, dan hsCRP $(\mathrm{r}=0,522 ; \mathrm{p}<0,05)$, juga terdapat pola peningkatan HbA1c, glukosa puasa, insulin puasa, dan HOMA-IR pada setiap tahap perkembangan DM. HOMA-B meningkat hingga pre-DM kemudian turun pada DM. Insulin puasa, HOMA-IR, HOMA-B, dan hsCRP lebih tinggi pada obesitas sentral non-DM dibandingkan kontrol. Terdapat korelasi positif antara hsCRP dengan $\mathrm{HbA} 1 \mathrm{c}(\mathrm{r}=0,484 ; \mathrm{p}<0,05)$, insulin puasa $(r=0,629 ; \mathrm{p}<0,05)$, HOMA-IR $(\mathrm{r}=0,602 ; \mathrm{p}<0,05)$, dan HOMA-B $(\mathrm{r}=0,540 ; \mathrm{p}<0,05)$. Terdapat peningkatan insulin puasa dan HOMA-IR pada obesitas sentral dengan pre-DM dibandingkan dengan obesitas sentral nonDM. Penelitian ini memberikan informasi pola penanda glikemik dan inflamasi pria dengan obesitas sentral pada perkembangan penyakit DM. Pengetahuan mengenai pola perkembangan DM dapat memberikan informasi bahwa DM pada obesitas sentral dapat dicegah sedini mungkin sehingga prevalensinya dapat dikendalikan.
\end{abstract}

Kata kunci: Diabetes melitus, inflamasi, obesitas sentral, resistensi insulin

\section{Glycemic and Inflammation Markers Pattern of Type 2 Diabetes Mellitus Disease Progression in Centrally Obese Men}

\begin{abstract}
Central obesity is a health problem whose prevalence continues to increase. Central obesity has been known to be a risk factor that is strongly associated with diabetes mellitus (DM). Central obesity triggers inflammation which causes insulin resistance and increases the function of pancreatic beta cells as compensatory mechanism before its exhausted. Therefore, we need to know the patter of glycemic and inflammatory markers in the disease development of DM. This study aimed to determine the pattern of glycemic and inflammatory markers in the development of DM in men with central obesity. This study was conducted with a cross-sectional approach to 70 men aged 30-50 years in Jakarta, Bandung, Semarang, and Bogor with waist circumference of more than $90 \mathrm{~cm}$ who met the inclusion and exclusion criteria and examined $\mathrm{HbA} 1 \mathrm{c}$, fasting insulin, fasting glucose, and hsCRP. HOMA-IR and HOMA-B were obtained from mathematical modeling for fasting insulin and fasting glucose. Recruitment is carried out in November-December 2017. The result shows that there was significantly positive correlation between waist circumference with HbA1c $(r=0.484 ; p<0.05)$, fasting insulin $(r=0.629 ; p<0.05)$, HOMA-IR $(r=0.602 ; p<0.05)$, HOMA-B $(r=0.540 ; p<0.05)$, and hsCRP $(r=0.522 ; \mathrm{p}<0.05)$. There was an increasing pattern of HbAlc, fasting glucose, fasting insulin, HOMA-IR, and hsCRP, in every step of DM progression. Meanwhile, HOMA-B increased until central obesity with pre DM condition and decreased in central obesity with DM condition. There was an increase of fasting insulin, HOMA-IR, HOMA-B, and hsCRP in central obese without DM-men compared to control. There was a positive correlation between hsCRP and HbA1c $(r=0.484 ; \mathrm{p}<0.05)$, fasting insulin $(\mathrm{r}=0.629$; $p<0.05)$, HOMA-IR $(r=0.602 ; p<0.05)$, and HOMA-B $(r=0.540 ; p<0.05)$. There was an increase of fasting insulin and HOMA-IR in central obese without DM-men compared to central obese with pre DM-men. This study provides information on patterns of glycemic and inflammatory markers of men with central obesity in the disease development of DM. Knowledge about the pattern of DM development can provide information that DM in central obesity can be prevented as early as possible so that its prevalence can be controlled.
\end{abstract}

Keywords: Central obesity, diabetes mellitus, insulin resistance, inflammation

Korespondensi: Miftakh N. Rahman, M.Farm., PT. Prodia Widyahusada Tbk., Jakarta Pusat, DKI Jakarta 10430, Indonesia, email: miftakh.nur@prodia.co.id

Naskah diterima: 8 Februari 2018, Diterima untuk diterbitkan: 13 November 2019, Diterbitkan: 28 Desember 2019 


\section{Pendahuluan}

Peningkatan massa tubuh merupakan sebuah permasalahan kesehatan yang terus meningkat berjalan seiring dengan gaya hidup sedenter, kebiasaan yang buruk dalam pola makan, pengaruh sosio-ekonomi masyarakat, serta dalam beberapa kasus disebabkan peran gen. ${ }^{1}$ Obesitas didefinisikan sebagai peningkatan massa tubuh total akibat kelebihan lemak. ${ }^{2}$ Patogenesis obesitas diawali dengan kondisi nutrisi yang berlebih sehingga terjadi kelainan dalam metabolisme energi dan penumpukan lemak viseral di daerah perut. Obesitas dengan tanda tersebut dinamakan sebagai obesitas sentral yang dinilai memiliki asosiasi yang lebih kuat dengan diabetes melitus (DM). ${ }^{3}$ Obesitas sentral memicu terjadinya inflamasi derajat rendah yang dapat berlangsung dalam jangka waktu yang lama. Inflamasi tersebut dipicu secara metabolik yang dikenal sebagai metaflammation. ${ }^{4}$ Berdasarkan International Obesity Task Force (IOTF), kriteria obesitas sentral untuk asia pasifik dinyatakan dengan lingkar perut sebesar $\geq 90 \mathrm{~cm}$ untuk pria dan $\geq 80 \mathrm{~cm}$ untuk wanita. ${ }^{5}$ Riset Kesehatan Dasar (Riskesdas) yang dilakukan oleh Kementerian Kesehatan Republik Indonesia pada tahun 2013 menyatakan bahwa prevalensi obesitas sentral mencapai $26,6 \%,{ }^{6}$ dan data tersebut menunjukkan peningkatan karena prevalensi obesitas sentral pada hasil studi sebelumnya di tahun 2007 adalah 18,8\%. ${ }^{7}$ Peningkatan prevalensi obesitas sentral ini sejalan dengan peningkatan prevalensi penyandang $\mathrm{DM} .{ }^{6,7}$

Penyakit DM memiliki prevalensi yang terus meningkat. Prevalensi DM di dunia adalah $4,7 \%$ pada tahun 1980 dan meningkat menjadi $8,5 \%$ pada tahun $2014 .{ }^{8}$ Hal yang sama juga terjadi di Indonesia, berdasarkan data Riskesdas pada tahun 2007, prevalensi DM yang terdiagnosis adalah $1,1 \%$ dan pada tahun 2013 meningkat menjadi 2,1\%. ${ }^{6,7}$ Patogenesis DM didahului oleh kondisi resistensi insulin yang berimplikasi pada peningkatan fungsi sel beta pankreas sebagai kompensasi. Resistensi insulin dapat dikuantifikasi dengan melalui permodelan matematika yang dikenal dengan Homeostasis Model Assesment for Insulin Resistance (HOMA-IR) sedangkan fungsi sel beta pankreas dapat dikuantifikasi dengan permodelan matematika yang dikenal dengan Homeostasis Model Assesment for Beta Cell (HOMA-B). ${ }^{9,10}$ Kedua permodelan matematika tersebut diperoleh dari glukosa puasa dan insulin puasa.

Peningkatan prevalensi obesitas sentral yang sejalan dengan peningkatan prevalensi DM akan menunjukkan pola pada obesitas sentral dalam perkembangannya menjadi DM. Studi ini menggabungkan penanda glikemik dan inflamasi secara simultan sehingga dapat memberi informasi lengkap serta diharapkan juga dapat menunjukkan pola pada penyakit DM. Jika pola perkembangan penyakit DM dapat diketahui pada obesitas sentral bahkan sebelum terjadinya DM, maka kejadian DM dapat dicegah sedini mungkin. Penelitian ini bertujuan untuk mengetahui pola penanda glikemik dan inflamasi yang terlibat dalam perkembangan penyakit DM dan korelasinya dengan obesitas sentral.

\section{Metode}

Penelitian dilakukan pada bulan NovemberDesember tahun 2017 di Jakarta, Bandung, Semarang, dan Bogor. Sebelum penelitian ini dimulai, dilakukan pengajuan izin etik kepada Komisi Etik Penelitian Kesehatan Fakultas Kedokteran Universitas Padjadjaran. Penelitian ini dilakukan secara observasional dengan pendekatan potong-lintang terhadap pria berusia 30-50 tahun dengan lingkar perut $\geq 90 \mathrm{~cm}$. Subjek pria dipilih dengan alasan untuk mengurangi bias hormonal. Setiap subjek yang telah mendapatkan penjelasan dan telah setuju untuk berpartisipasi dalam penelitian kemudian mengisi kuisioner dan dilakukan pengambilan darah vena sebanyak 
$9 \mathrm{~mL}$ (6 mL tabung tanpa antikoagulan dan 3 $\mathrm{mL}$ tabung dengan antikoagulan EDTA untuk pemeriksaan $\mathrm{HbA1c}$ ) oleh petugas terlatih. Sebanyak $6 \mathrm{~mL}$ darah yang diambil dengan tabung antikoagulan kemudian disentrifugasi sehingga diperoleh serum untuk pemeriksaan laboratorium skrining dan penanda glikemik serta inflamasi. Adapun pemeriksaan skrining meliputi hsCRP, SGOT, SGPT, kreatinin, dan estimasi laju filtrasi glomerulus (eLFG). Kriteria eksklusi pada penelitian ini adalah tidak mengalami inflamasi akut yang ditandai dengan hsCRP $>10 \mathrm{mg} / \mathrm{dL}$, tidak mengalami gangguan fungsi hati yang ditandai dengan nilai $\mathrm{SGOT}>66 \mathrm{U} / \mathrm{L}$ dan $\mathrm{SGPT}>100 \mathrm{U} / \mathrm{L}$, serta tidak mengalami kerusakan ginjal yang ditandai dengan eLFG $<60 \mathrm{~mL} / \mathrm{menit} / 1,73 \mathrm{~m}^{2}$. Subjek yang memenuhi kriteria inklusi dan eksklusi lalu menjalani pemeriksaan $\mathrm{HbA1c}$, glukosa puasa, insulin puasa, HOMA-IR, dan HOMA-B. Penentuan status non-DM, pre-DM dan DM dinyatakan dengan berdasar pada konsentrasi HbAlc menurut kriteria American Diabetes Association (ADA). ${ }^{11}$ Pria berusia 30-50 tahun yang memiliki lingkar perut $<90 \mathrm{~cm}$ dan tidak menyandang DM serta memenuhi kriteria eksklusi menjadi pembanding untuk meyakinkan bahwa terjadi perubahan penanda glikemik dan inflamasi pada obesitas sentral. Seluruh pemeriksaan laboratorium dilakukan di Laboratorium Klinik Prodia. Metode pemeriksaan untuk hsCRP adalah imunoturbidimetri, sedangkan metode pemeriksaan glukosa puasa, SGOT, SGPT, dan kreatinin adalah enzimatik kolorimetri. Pemeriksaan insulin dilakukan menggunakan metode Chemiluminescent Immunoassay (CLIA), sedangkan pemeriksaan HbAlc menggunakan metode High Performance Liquid Chromatography-Ion Exchange (HPLC-IE) yang telah tersertifikasi National Glycohemoglobine Standardization Program (NGSP). Data diolah secara deskriptif, uji korelasi menggunakan uji Spearman, uji beda bivariat menggunakan uji Mann-Whitney-U sedangkan uji beda multivariat menggunakan uji Kruskal-Wallis dengan tingkat kepercayaan 95\%. Analisis data menggunakan perangkat lunak SPSS 24.

\section{Hasil}

Penelitian ini telah disetujui oleh Komisi Etik Penelitian Kesehatan Fakultas Kedokteran Universitas Padjadjaran dengan nomor 1039/ UN6.C.10/PN/2017. Diperoleh sebanyak 90 orang pria yang memenuhi kriteria inklusi dan eksklusi dengan komposisi 70 orang yang dinyatakan sebagai obesitas sentral dan 20 orang sebagai non-obesitas sentral. Dari total 70 orang subjek obesitas sentral, sebanyak 37 orang $(52,8 \%)$ di antaranya tidak memiliki DM, 22 orang $(31,4 \%)$ sudah berkembang menjadi pre-DM, dan 11 orang $(15,7 \%)$ telah menyandang DM. Karakteristik subjek pada penelitian ini ditunjukkan pada Tabel 1 .

Penelitian ini juga menunjukkan bahwa terdapat korelasi positif antara lingkar perut dengan HbA1c, insulin puasa, HOMA-IR, dan HOMA-B, namun tidak terdapat korelasi dengan glukosa puasa. Selain itu, ditemukan adanya korelasi antara lingkar perut dengan konsentrasi hsCRP. Data ditunjukkan pada Tabel 2.

Penentuan status DM dilakukan berdasar pada konsentrasi $\mathrm{HbA1c}$ menurut $\mathrm{ADA}^{11}$ yang menyatakan bahwa konsentrasi HbAlc non-DM adalah $<5,7 \%$, pre-DM adalah 5,7$6,4 \%$, dan DM adalah $>6,5 \%$. Pada penelitian ini, pola konsentrasi $\mathrm{HbA1c}$, glukosa puasa, insulin puasa, HOMA-IR, dan HOMA-B serta hsCRP pada perjalanan penyakit DM ditunjukkan pada Tabel 3.

Hasil penelitian ini menunjukkan bahwa insulin puasa, HOMA-IR, HOMA-B, dan hsCRP pada subjek obesitas sentral tanpa DM lebih tinggi dibandingkan dengan subjek nonobesitas sentral, namun belum terlihat adanya peningkatan glukosa puasa. Data ditunjukkan pada Tabel 4. 
Tabel 1 Karaktersitik Subjek Penelitian

\begin{tabular}{|c|c|c|c|}
\hline \multirow{3}{*}{ Variabel } & \multicolumn{2}{|c|}{ Kelompok Subjek } & \multirow{3}{*}{ Nilai-p } \\
\hline & Non-obesitas Sentral & Obesitas Sentral & \\
\hline & $(n=20)$ & $(n=70)$ & \\
\hline Usia (tahun) & $39 \pm 6$ & $40 \pm 6$ & 0,448 \\
\hline Lingkar Perut $(\mathrm{cm})$ & $81 \pm 7$ & $104 \pm 9$ & $<0,001^{*}$ \\
\hline $\operatorname{IMT}\left(\mathrm{kg} / \mathrm{m}^{2}\right)$ & $23 \pm 3$ & $31 \pm 4$ & $<0,001^{*}$ \\
\hline SGOT (U/L) & $20 \pm 5$ & $26 \pm 8$ & $0,005^{*}$ \\
\hline SGPT (U/L) & $20 \pm 10$ & $37 \pm 18$ & $<0,001^{*}$ \\
\hline eLFG (mL/menit/1,73 m²) & $98 \pm 11$ & $103 \pm 13$ & 0,103 \\
\hline hsCRP (mg/L) & $0,8 \pm 0,6$ & $3,5 \pm 2,4$ & $<0,001 *$ \\
\hline Non-DM & 20 & $37(52,8 \%)$ & \\
\hline Pre-DM & - & $22(31,4 \%)$ & \\
\hline DM & - & $11(15,7 \%)$ & \\
\hline
\end{tabular}

Terdapat korelasi antara hsCRP dengan HbA1c, insulin puasa, HOMA-IR, serta HOMA-B seperti yang terlihat pada Tabel 5 . Peningkatan yang signifikan ditemukan pada insulin puasa dan HOMA-IR pada obesitas sentral dengan pre-DM dibandingkan dengan obesitas sentral non-DM. Akan tetapi, pada glukosa puasa, HOMA-B, dan hsCRP, tidak terdapat peningkatan yang signifikan pada obesitas sentral dengan pre-DM dibandingkan obesitas sentral non-DM. Data ditunjukkan pada Tabel 6 .

\section{Pembahasan}

Obesitas sentral telah diketahui berasosiasi kuat dengan DM. Akumulasi lemak di perut mengakibatkan kerusakan jaringan lemak itu sendiri melalui proses inflamasi. Inflamasi yang terjadi akan menyebar ke jaringan lain secara sistemik ataupun portal termasuk ke hati, jaringan otot, dan pankreas. Dengan demikian, lingkar perut yang semakin besar akan meningkatkan risiko terjadinya $\mathrm{DM}^{2,3}$ Pada hasil penelitian ini, ditemukan adanya korelasi positif yang signifikan antara lingkar perut dengan $\mathrm{HbA1c}$, insulin puasa, HOMAIR, HOMA-B, dan hsCRP. Apabila ditinjau dari mekanismenya, akumulasi lemak di perut akan mengakibatkan inflamasi yang kemudian dapat berkembang menjadi resistensi insulin. ${ }^{12}$ Resistensi insulin akan merangsang sel beta pankreas untuk meningkatkan aktivitasnya sehingga konsentrasi insulin pun meningkat. ${ }^{13}$ Jika berlangsung dalam waktu yang lama, resistensi insulin akan semakin berat dan sel

Tabel 2 Korelasi Penanda Glikemik dan Inflamasi dengan Lingkar Perut

\begin{tabular}{lcc}
\hline \multicolumn{1}{c}{ Variabel } & \multicolumn{2}{c}{ Lingkar Perut $(\mathbf{n = 9 0 )}$} \\
\cline { 2 - 3 } & Koefisien Korelasi & Nilai-p \\
\hline HbA1c $(\mathrm{n}=90)$ & 0,484 & $<0,05^{*}$ \\
Glukosa Puasa $(\mathrm{n}=90)$ & 0,118 & 0,270 \\
Insulin Puasa $(\mathrm{n}=90)$ & 0,629 & $<0,05^{*}$ \\
HOMA-IR $(\mathrm{n}=90)$ & 0,602 & $<0,05^{*}$ \\
HOMA-B $(\mathrm{n}=90)$ & 0,540 & $<0,05^{*}$ \\
hSCRP $(\mathrm{n}=90)$ & 0,522 & $<0,05^{*}$ \\
\hline
\end{tabular}

*Signifikan pada tingkat kepercayaan 95\% menggunakan uji korelasi Spearman 
Tabel 3 Profil Penanda Glikemik dan Inflamasi Perkembangan Penyakit Diabetes Melitus pada Obesitas Sentral

\begin{tabular}{lccccc}
\hline & \multicolumn{4}{c}{ Perkembangan Penyakit DM pada Obesitas Sentral } & \\
\cline { 2 - 5 } \multicolumn{1}{c}{ Variabel } & $\begin{array}{c}\text { Non-obesitas } \\
\text { Sentral }\end{array}$ & $\begin{array}{c}\text { Obesitas Sentral } \\
\text { Non-DM }\end{array}$ & $\begin{array}{c}\text { Obesitas Sentral } \\
\text { Pre-DM }\end{array}$ & $\begin{array}{c}\text { Obesitas Sentral } \\
\text { DM }\end{array}$ & \multirow{2}{*}{ Nilai-p } \\
\cline { 2 - 5 } & $\mathbf{( n = 2 0 )}$ & $\mathbf{( n = 3 7 )}$ & $\mathbf{( n = 2 2 )}$ & $\mathbf{( n = 1 1 )}$ & \\
\hline HbA1c (\%) & $5,2 \pm 0,2$ & $5,3 \pm 0,3$ & $5,9 \pm 0,2$ & $9,1 \pm 2,3$ & $<0,05^{*}$ \\
Glukosa Puasa (mg/dL) & $88 \pm 8$ & $86 \pm 7$ & $90 \pm 10$ & $165 \pm 65$ & $<0,05^{*}$ \\
Insulin Puasa (uIU/mL) & $4 \pm 3$ & $10 \pm 6$ & $14 \pm 8$ & $22 \pm 13$ & $<0,05^{*}$ \\
HOMA-IR & $0,8(0,5-2,4)$ & $1,7(1,2-4,6)$ & $2,9(2,1-7,0)$ & $7,1(3,4-22,6)$ & $<0,05^{*}$ \\
HOMA-B & $73(31-123)$ & $145(96-368)$ & $185(141-366)$ & $65(31-253)$ & $<0,05^{*}$ \\
hsCRP (mg/L) & 0,8 & 3,1 & 3,6 & 5,0 & $<0,05^{*}$ \\
\hline Keterangan: DM=Diabetes melitus; *Signifikan pada tingkat kepercayaan 95\% dengan uji Kruskal-Wallis &
\end{tabular}

beta akan kehilangan fungsinya, sehingga terjadilah peningkatan $\mathrm{HbAlc}$ dan glukosa puasa sebagai penanda untuk penegakkan diagnosis DM. Pada hasil penelitian ini, tidak ditemukan adanya korelasi antara lingkar perut dengan glukosa puasa yang disebabkan oleh mekanisme kompensasi pankreas untuk menormalisasi konsentrasi glukosa darah. ${ }^{14}$

Terdapat pola peningkatan $\mathrm{HbA} 1 \mathrm{c}$, insulin puasa, HOMA-IR, HOMA-B, serta hsCRP pada setiap tahapan terjadinya penyakit DM. Pada perkembangan DM, kondisi kritis yang menjadi perhatian adalah kondisi pre-DM. Kondisi tersebut umumnya tidak disadari, dan apabila dibiarkan akan terus berkembang menjadi DM dengan risiko sebesar 6 kali lebih tinggi. ${ }^{11}$ Apabila gangguan metabolisme glukosa telah diketahui sejak kondisi pre-DM, maka perkembangan DM dapat dicegah. Hal ini karena DM masih bersifat reversibel yang berarti dapat kembali normal jika pola hidup dan asupan nutrisi diperbaiki. ${ }^{15}$ Berdasarkan data hasil, resistensi insulin yang ditunjukkan dengan HOMA-IR terus meningkat seiring dengan perjalanan DM dan diikuti dengan peningkatan HOMA-B yang berarti telah terjadi kompensasi dari sel beta pankreas. Namun, pada saat sel beta sudah tidak dapat mengompensasi, kondisi DM akan semakin buruk karena insulin tidak dapat dihasilkan. ${ }^{16}$ Resistensi insulin dianggap telah terjadi jika nilai HOMA-IR $\geq 2 .{ }^{10}$ Resistensi insulin telah terjadi pada kondisi obesitas sentral dengan pre-DM (HOMA-IR=2,9 $(2,1-7,0))$ yang disertai peningkatan aktivitas sel beta (HOMA-B=185 (141-366)). Aktivitas normal

Tabel 4 Profil Glukosa Puasa, Insulin Puasa, HOMA-IR, HOMA-B, dan hsCRP pada Obesitas Sentral Tanpa Diabetes Melitus Dibandingkan Kontrol

\begin{tabular}{|c|c|c|c|}
\hline \multirow{3}{*}{ Variabel } & \multicolumn{2}{|c|}{ Kasus } & \multirow{3}{*}{ Nilai-p } \\
\hline & Non-obesitas Sentral & Obesitas Sentral Non-DM & \\
\hline & $(n=20)$ & $(n=37)$ & \\
\hline Glukosa Puasa (mg/dL) & $88 \pm 8$ & $86 \pm 7$ & 0,288 \\
\hline Insulin Puasa (uIU/mL) & $4 \pm 3$ & $10 \pm 4$ & $<0,05^{*}$ \\
\hline HOMA-IR & $0,8(0,5-2,4)$ & $1,7(1,2-4,6)$ & $<0,05^{*}$ \\
\hline HOMA-B & $73(31-123)$ & $145(96-368)$ & $<0,05^{*}$ \\
\hline hsCRP (mg/L) & 0,8 & 3,1 & $<0,05^{*}$ \\
\hline
\end{tabular}


Tabel 5 Korelasi antara hsCRP dengan HbA1c, Insulin Puasa, HOMA-IR, dan HOMA-B

\begin{tabular}{lcc}
\hline \multicolumn{1}{c}{ Variabel } & \multicolumn{2}{c}{ hsCRP $(\mathbf{n}=90)$} \\
\cline { 2 - 3 } & Koefisien Korelasi & Nilai-p \\
\hline HbA1c $(\mathrm{n}=90)$ & 0,484 & $<0,05^{*}$ \\
Insulin Puasa $(\mathrm{n}=90)$ & 0,629 & $<0,05^{*}$ \\
HOMA-IR $(\mathrm{n}=90)$ & 0,602 & $<0,05^{*}$ \\
HOMA-B $(\mathrm{n}=90)$ & 0,540 & $<0,05^{*}$ \\
\hline *Signifkan
\end{tabular}

*Signifikan pada tingkat kepercayaan 95\% menggunakan uji korelasi Spearman

sel beta adalah $70-150 \% .{ }^{10}$ Jika HOMA-B telah melebihi $150 \%$, maka terjadi aktivitas berlebih dari sel beta yang berujung pada hilangnya fungsi sel beta. Kerusakan sel beta juga dapat lebih cepat terjadi jika inflamasi meningkat. ${ }^{17,18}$ Kondisi inflamasi meningkat seiring dengan perkembangan penyakit DM yang terlihat dari peningkatan hsCRP.

Perubahan penanda glikemik dan inflamasi telah terjadi pada kondisi obesitas sentral walaupun belum berkembang menjadi pre-DM maupun DM. Data hasil menunjukkan bahwa terdapat peningkatan insulin puasa, HOMAIR, HOMA-B, serta hsCRP walaupun belum terlihat adanya peningkatan glukosa puasa. Glukosa puasa meningkat saat telah terjadi kondisi DM dengan konsentrasi 165 65 $\mathrm{mg} / \mathrm{dL}$. Nilai tersebut sesuai dengan kriteria diagnosis DM jika diperoleh glukosa puasa $\geq 126 \mathrm{mg} / \mathrm{dL}$. Peningkatan HOMA-IR pada kondisi obesitas adalah efek dari peningkatan inflamasi yang dapat dilihat dari peningkatan korelasi antara hsCRP dengan HOMA-IR. Peningkatan HOMA-IR pada obesitas sentral
non-DM menunjukkan adanya potensi resistensi insulin yang masih dapat dikompensasi oleh sel beta pankreas dengan cara meningkatkan aktivitasnya. ${ }^{19}$ Hal tersebut terlihat pula dari peningkatan HOMA-B yang signifikan pada obesitas sentral non-DM dibandingkan dengan kontrol. Namun demikian, kerusakan sel beta juga dapat menjadi lebih cepat akibat inflamasi yang terlihat dari korelasi antara HOMA-B dengan hsCRP.

Hasil penelitian ini menunjukkan terdapat peningkatan insulin puasa dan HOMA-IR yang signifikan pada subjek obesitas sentral non-DM yang berkembang menjadi preDM tanpa diikuti oleh peningkatan glukosa puasa, HOMA-B, dan hsCRP. Berdasarkan hasil tersebut, perkembangan pre-DM dapat dipantau melalui proses resistensi insulin yang disertai dengan peningkatan konsentrasi insulin untuk mempertahankan konsentrasi glukosa darah. Hal tersebut terlihat dari konsentrasi glukosa puasa yang berada pada nilai normal $(90 \pm 10 \mathrm{mg} / \mathrm{dL})$. Pada kondisi pre-DM terlihat bahwa tubuh masih mampu

Tabel 6 Profil Glukosa Puasa, Insulin Puasa, HOMA-IR, HOMA-B, dan hsCRP pada Obesitas Sentral Tanpa Diabetes Melitus Dibandingkan Obesitas Sentral dengan Pre-Diabetes Melitus

\begin{tabular}{|c|c|c|c|}
\hline \multirow{3}{*}{ Variabel } & \multicolumn{2}{|c|}{ Kasus } & \multirow{3}{*}{ Nilai-p } \\
\hline & Obesitas Sentral Non-DM & Obesitas Sentral Pre-DM & \\
\hline & $(n=37)$ & $(n=22)$ & \\
\hline Glukosa Puasa (mg/dL) & $86 \pm 7$ & $90 \pm 10$ & 0,13 \\
\hline Insulin Puasa (uIU/mL) & $10 \pm 6$ & $14 \pm 8$ & $<0,05^{*}$ \\
\hline HOMA-IR & $1,7(1,2-4,6)$ & $2,9(2,1-7,0)$ & $<0,05^{*}$ \\
\hline HOMA-B & $145(96-368)$ & $185(141-366)$ & 0,19 \\
\hline hsCRP (mg/L) & 3,1 & 3,6 & 0,59 \\
\hline
\end{tabular}


untuk mengompensasi kelainan metabolik.

Data penelitian diperoleh sebatas rancangan potong lintang yang hanya menunjukkan pola perkembangan DM pada setiap tahapan berdasarkan konsentrasi HbA1c. Diperlukan penelitian dengan rancangan kohort untuk mengikuti perjalanan DM supaya diperoleh pola yang lebih detail dan dapat membangun kombinasi marker untuk deteksi dini DM dan komplikasinya serta menilai intervensi yang dapat diberikan untuk manajemen obesitas agar tidak berkembang menjadi DM..$^{20,21}$

\section{Simpulan}

Penelitian ini memberikan informasi pola penanda glikemik dan inflamasi pria dengan obesitas sentral pada perkembangan penyakit DM. Resistensi insulin meningkat seiring dengan kondisi inflamasi dan diikuti oleh peningkatan aktivitas sel beta agar konsentrasi glukosa darah tetap normal. Resistensi insulin dan fungsi sel beta pankreas yang berlebihan terjadi pada kondisi obesitas sentral dengan pre-DM yang kemudian berkembang lebih lanjut menjadi DM.

\section{Pendanaan}

Penelitian ini mendapatkan bantuan dana dari PT. Prodia Widyahusada, Tbk. dalam rangka beasiswa Pendidikan Magister di Fakultas Farmasi Universitas Padjadjaran.

\section{Ucapan Terima Kasih}

Peneliti mengucapkan terima kasih kepada Bapak Andi Wijaya yang telah memberikan beasiswa untuk pendidikan Magister di bidang Farmasi.

\section{Konflik Kepentingan}

Seluruh penulis menyatakan tidak terdapat potensi konflik kepentingan dengan penelitian, kepenulisan (authorship), dan atau publikasi artikel ini.

\section{Daftar Pustaka}

1. McArdle MA, Finucane OM, Connaughton RM, McMorrow AM, Roche HM. Mechanisms of obesityinduced inflammation and insulin resistance: Insights into the emerging role of nutritional strategies. Front Endocrinol. 2013;44:52. doi: 10.3389/fendo.2013.00 052

2. Castro AVB, Kolka CM, Kim SP, Bergman RN. Obesity, insulin resistance and comorbidities-Mechanisms of association. Arq Bras Endocrinol Metabol. 2014;58(6):600-9. doi: 10.1590/0004-27 30000003223

3. Rachmi CN, Li M, Alison Baur L. Overweight and obesity in Indonesia: Prevalence and risk factors - a literature review. Public Health. 2017;147:20-9. doi: 10.1016/j.puhe.2017.02.002.

4. Meiliana A, Wijaya A. Metaflammation, NLRP3 inflammasome obesity and metabolic disease. Indones Biomed $\mathrm{J}$. 2011;3(3):168-84. doi: 10.18585/inabj.v3 i3.148

5. World Health Organization. The Asia Pacific perspective: Redifining obesity and its treatment. Sydney: Health Communications Australia. 2000.

6. Badan Penelitian dan Pengembangan Kesehatan Kementerian Kesehatan Republik Indonesia. Riset kesehatan dasar 2013. Jakarta: Kementerian Kesehatan Republik Indonesia; 2013.

7. Badan Penelitian dan Pengembangan Kesehatan Kementerian Kesehatan Republik Indonesia. Riset kesehatan dasar 2007. Jakarta: Kementerian Kesehatan Republik Indonesia; 2007.

8. World Health Organization. Global report on diabetes. World Health Organization; 
2016.

9. Song Y, Manson JE, Tinker L, Howard BV, Kuller LH, Nathan L, et al. Insulin sensitivity and insulin secretion determined by homeostasis model assessment and risk of diabetes in a multiethnic cohort of women: the Women's Health Initiative Observational Study. Diabetes Care. 2007; 30(7):1747-52.

10. Tjokroprawiro A. Formula klinik praktis bidang diabetologi-endokrinologimetabolisme. Edisi ke-5. Surabaya: Pusat Diabetes dan Nutrisi Surabaya-Fakultas Kedokteran Universitas Airlangga-RSUD Dr. Soetomo; 2017.

11. American Diabetes Association. Standards of medical care in diabetes-2009. Diab Care. 2009;32:(1):S13-61. doi: 10.2337/d c09-S013

12. Ye J. Mechanisms of insulin resistance in obesity. Front Med. 2013;7(1):14-24. doi: 10.1007/s11684-013-0262-6.

13. Mayans L. Metabolic syndrome: Insulin resistance and prediabetes. FP Essent. 2015;435:11-6.

14. Alejandro EU, Gregg B, BlandinoRosano M, Cras-Méneur C, BernalMizrachi E. Natural history of $\beta$-cell adaptation and failure in type 2 diabetes. Mol Aspects Med. 2015;42:19-41. doi: 10.1016/j.mam.2014.12.002.

15. Soewondo P, Pramono LA. Prevalence, characteristics, and predictors of prediabetes in Indonesia. Med J Indones. 2011;20(4):283-94. doi: 10.13181/mji.v20 i4. 465
16. Ashcroft FM, Rorsman P. Diabetes mellitus and the $\beta$ cell: The last ten years. Cell. 2012;148(6):1160-71. doi: 10.1016/ j.cell.2012.02.010.

17. Butler AE, Dhawan S. $\beta$-Cell identity in type 2 diabetes: Lost or found? Diabetes. 2015;64(8):2698-700. doi: 10.2337/db15 $-0550$

18. Russo GT, Giorda CB, Cercone S, Nicolucci A, Cucinotta D, BetaDecline Study Group. Factors associated with beta-cell dysfunction in type 2 diabetes: the BETADECLINE study. PLoS One. 2014;9(10):e109702. doi: 10.1371/journa 1.pone.0109702

19. Baranyi A, Amouzadeh-Ghadikolai O, von Lewinski D, Rothenhäusler H-B, Theokas S, Robier C, et al. Branchedchain amino acids as new biomarkers of major depression-A novel neurobiology of mood disorder. PLoS One. 2016;11(8): e0160542. doi: 10.1371/journal.pone.016 0542.

20. Stokes A, Collins JM, Grant BF, Scamuffa RF, Hsiao C-W, Johnston SS, et al.Obesity progression between young adulthood and midlife and incident diabetes: A retrospective cohort study of u.s. Adults. Diabetes Care. 2018;41(5):1025-31. doi: 10.2337/dc17-2336.

21. Kim ES, Jeong JS, Han K, Kim MK, Lee $\mathrm{SH}$, Park YM, et al. Impact of weight changes on the incidence of diabetes mellitus: A Korean nationwide cohort study. Sci Rep. 2018;8(1):3735. doi: 10.1 038/s41598-018-21550-3 